\title{
Uvariopsis dicaprio (Annonaceae) a new tree species with notes on its pollination biology, and the Critically Endangered narrowly endemic plant species of the Ebo Forest, Cameroon
}

\author{
George Gosline ${ }^{\text {Equal first author, } 1}$, Martin Cheek ${ }^{\text {Corresp. Equal first author, } 1}$, Jean Michel Onana ${ }^{2,3}$, Eric Ngansop Tchatchouang ${ }^{3}$, \\ Xander M van der Burgt ${ }^{1}$, Lorna MacKinnon ${ }^{1}$, Léo-Paul M J Dagallier ${ }^{4}$ \\ ${ }^{1}$ Science, Royal Botanic Gardens, Kew, Richmond, Surrey, United Kingdom \\ 2 Faculty of Science, Department of Plant Biology, Université de Yaoundé I, Yaoundé, Cameroon \\ 3 National Herbarium of Cameroon, IRAD, Yaoundé, Cameroon \\ 4 DIADE, Univ Montpellier, CIRAD, IRD, Montpellier, France \\ Corresponding Author: Martin Cheek \\ Email address: m.cheek@kew.org
}

Background. The Ebo Forest area is a highly threatened centre of diversity in the Littoral Region of Cameroon, globally important for conservation with many threatened species including 68 threatened species of plant, yet not formally protected. The tropical African evergreen forest tree genus Uvariopsis Engl. \& Diels (Annonaceae) is characterised by unisexual, usually cauliflorous flowers with a uniseriate corolla of four petals, and two sepals. Cameroon is the centre of diversity of the genus with 14 of the 19 known species. Methods. The herbarium collection MacKinnon 51 from Ebo is hypothesized to represent a new species to science of Uvariopsis. This hypothesis is tested by the study of herbarium specimens from a number of herbaria known to hold important collections from Cameroon and surrounding countries. Results. We test the hypothesis that MacKinnon 51 represents a new species to science, using the most recent dichotomous identification key, and comparing it morphologically with reference material of all known species of the genus. We make a detailed comparative morphological study focussing on three other Cameroonian species, Uvariopsis solheidii, $U$. korupensis and the sympatric $U$. submontana. In the context of a review of the pollination biology of Uvariopsis, we speculate that in a genus otherwise with species with dull, flesh-coloured (pink, red to brown) flowers pollinated (where known) by diptera, orthoptera and blattodea (flies, crickets and cockroaches), the glossy, pale yellow-green flowers of Uvariopsis dicaprio, with additional traits unique in the genus, may be pollinated by nocturnal moths. Based on MacKinnon 51, we formally name Uvariopsis dicaprio Cheek \& Gosline (Annonaceae) as new to science, and we describe, and illustrate, and map it. Restricted so far to a single site in evergreen forest in the Ebo Forest, Littoral Region, Cameroon, Uvariopsis dicaprio is provisionally assessed as Critically Endangered using the IUCN 2012 standard because the
Peeri reviewing PDF (2021:04:60715:1:1:NEW 27 Oct 2021 ) 
forest habitat of this species remains unprotected, and there exist imminent threats of logging and conversion to plantations. Discussion We show that the highest density of species of the genus (12), and of narrow endemics (5), is found in the Cross-Sanaga Interval of SE Nigeria and Western Cameroon. A revised key to the 14 Cameroonian species of Uvariopsis is presented. We review the other seven narrowly endemic and threatened species unique to the Ebo forest of Cameroon and discuss the phytogeographic affinities of the area. Conclusions Uvariopsis dicaprio adds to the growing list of species threatened with extinction at Ebo Forest due to current anthropogenic pressures. 
1 Uvariopsis dicaprio (Annonaceae) a new tree species with notes on its pollination biology, and 2 the Critically Endangered narrowly endemic plant species of the Ebo Forest, Cameroon .

3

4 George Gosline ${ }^{1}$, Martin Cheek ${ }^{1}$, Jean Michel Onana ${ }^{2,3}$, Eric Ngansop ${ }^{2}$, Xander van der Burgt ${ }^{1}$, 5 Lorna MacKinnon ${ }^{1}$, Leo-Paul M. J. Dagallier ${ }^{4}$

6

$7 \quad{ }^{1}$ Herbarium, Royal Botanic Gardens, Kew, Richmond, Surrey TW9 3AE, U.K.

$8 \quad 2$ IRAD-National Herbarium of Cameroon, P.O. Box. 1601, Yaoundé, Cameroon

$9{ }^{3}$ Faculty of Science, Department of Plant Biology, University of Yaoundé I,

10 Yaoundé, Cameroon

$11{ }^{4}$ DIADE, Univ Montpellier, CIRAD, IRD, Montpellier, France.

12

13 Corresponding author:

14 Martin Cheek ${ }^{1}$

15

16 Email address: m.cheek@kew.org 
18

19

20

21

22

23

24

25

26

27

28

29

30

31

32

33

34

35

36

37

38

39

40

41

42

43

44

45

46

47

48

49

50

51

52

53

54

55

56

57

58

59

60

61

62

63

\section{Abstract}

Background. The Ebo Forest area is a highly threatened centre of diversity in the Littoral Region of Cameroon, globally important for conservation with many threatened species including 68 threatened species of plant, yet not formally protected. The tropical African evergreen forest tree genus Uvariopsis Engl. \& Diels (Annonaceae) is characterised by unisexual, usually cauliflorous flowers with a uniseriate corolla of four petals, and two sepals. Cameroon is the centre of diversity of the genus with 14 of the 19 known species.

Methods. The herbarium collection MacKinnon 51 from Ebo is hypothesized to represent a new species to science of Uvariopsis. This hypothesis is tested by the study of herbarium specimens from a number of herbaria known to hold important collections from Cameroon and surrounding countries.

Results. We test the hypothesis that MacKinnon 51 represents a new species to science, using the most recent dichotomous identification key, and comparing it morphologically with reference material of all known species of the genus. We make a detailed comparative morphological study focussing on three other Cameroonian species, Uvariopsis solheidii, U. korupensis and the sympatric $U$. submontana.

In the context of a review of the pollination biology of Uvariopsis, we speculate that in a genus otherwise with species with dull, flesh-coloured (pink, red to brown) flowers pollinated (where known) by diptera, orthoptera and blattodea (flies, crickets and cockroaches), the glossy, pale yellow-green flowers of Uvariopsis dicaprio, with additional traits unique in the genus, may be pollinated by nocturnal moths.

Based on MacKinnon 51, we formally name Uvariopsis dicaprio Cheek \& Gosline (Annonaceae) as new to science, and we describe, illustrate and map it.

Restricted so far to a single site in evergreen forest in the Ebo Forest, Littoral Region, Cameroon, Uvariopsis dicaprio is provisionally assessed as Critically Endangered using the IUCN 2012 standard because the forest habitat of this species remains unprotected, and there exist imminent threats of logging and conversion to plantations.

Discussion We show that the highest density of species of the genus (12), and of narrow endemics (5), is found in the Cross-Sanaga Interval of SE Nigeria and Western Cameroon. A revised key to the 14 Cameroonian species of Uvariopsis is presented.

We review the other seven narrowly endemic and threatened species unique to the Ebo forest of Cameroon and discuss the phytogeographic affinities of the area.

Conclusions Uvariopsis dicaprio adds to the growing list of species threatened with extinction at Ebo Forest due to current anthropogenic pressures.

Key Words: cauliflorous, conservation, Cross-Sanaga Interval, moth-pollination, threatened species.

\section{Introduction}

A long-running survey of plants in Cameroon to support improved conservation management has been in course since 1992. The survey is led by botanists from the Royal Botanic Gardens, Kew and IRAD (Institute of Agricultural Research for Development)-National Herbarium of Cameroon, Yaoundé. The study has focussed on the Cross-Sanaga interval (Cheek et al., 2001, 2006) which contains the area with the highest plant species and generic diversity per degree square in tropical Africa (Barthlott et al., 1996, Dagallier et al., 2020). The herbarium specimens collected in these surveys formed the foundations for a series of Conservation Checklists (see 
64 below). So far, over 100 new species and several new genera have been discovered and 65 published, new protected areas have been recognised and the results of analysis are feeding into

66

67 68

69

70

71

72

73

74

75

76

77

78

79

80

81

82

83

84

85

86

87

88

89

90

91

92

93

94

95

96

97

98

99

100

101

102

103

104

105

106

107

108

109 the Cameroon Important Plant Area programme (https://www.kew.org/science/ourscience/projects/tropical-important-plant-areas-cameroon), based on the categories and criteria of Darbyshire et al., (2017).

In connection with preparation of a Conservation Checklist of the plants of the Ebo Forest, Littoral Region, a plant specimen (MacKinnon 51, Fig. 1 -3) was identified as an Uvariopsis Engl. \& Diels which resembled no other species known in the genus. In this paper we test the hypothesis that it is a new species to science endemic to Ebo and name the new species as Uvariopsis dicaprio. We also review other endemic and near-endemic plant species of the Ebo Forest (see Discussion).

Uvariopsis (Annonaceae, subfamily Annonoideae, tribe Monodoreae (Chatrou et al., 2012; Guo et al., 2017) is a highly distinctive and easily recognised genus, since most of its species have unisexual flowers, a calyx with two basally connate sepals, and the petals in a single whorl of four (very rarely three, see below). Annonaceae are otherwise characterised by bisexual flowers with trimerous perianths (van Heusden 1992). Most species of the genus Uvariopsis are cauliflorous small trees, the flowers being produced from the trunk, although some species are ramiflorous or bear axillary flowers (Kenfack et al., 2003, Couvreur et al., 2021 in press).

Nineteen species are currently accepted in Uvariopsis. Five species have been published in the $21^{\text {st }}$ Century: Uvariopsis korupensis Gereau \& Kenfack (Gereau \& Kenfack 2000), U. submontana Kenfack, Gosline \& Gereau (Kenfack et al., 2003) and U. etugiana Dagallier \& Couvreur (Couvreur et al., in press) all from Cameroon, U. citrata Couvreur \& Niang. (Couvreur \& Niangadouma 2016) from Gabon and U. lovettiana Couvreur \& Q. Luke (Couvreur \& Luke 2010) from Tanzania. In addition a sixth species, Uvariopsis tripetala (Baker f.) G.E.Schatz, was transferred to the genus from the monotypic Dennettia Baker f. (Kenfack et al., 2003), although it is likely that Dennettia should be reinstated (Cheek et al., 2021a). The genus is centred in Cameroon, where 13 of the 19 species occur, followed in species diversity by Gabon, with six species. The most widespread species of the genus is Uvariopsis congensis Robyns \& Ghesq. which occurs from Cameroon to South Sudan, Zambia and Kenya. Several species are rare, being known from only one or two specimens and have restricted ranges, these include $U$. etugiana (Cameroon endemic) and U. citrata (Cameroon \& Gabon), both known from two specimens, and U. sessiliflora (Mildbr. \& Diels) Robyns \& Ghesq. endemic to Cameroon and known from a single specimen.

The genus is distributed throughout continental tropical African evergreen forests, from Guinea in the West to Tanzania in the east, and as far south as northern Zambia. The species usually occur at low altitude, exceptions including $U$. submontana and $U$. lovettiana which occur in submontane or cloud forest in Cameroon and Tanzania respectively (Kenfack et al., 2003; Couvreur \& Luke 2010). Species are usually small trees in high quality, undisturbed forest and appear not to be pioneers. They usually occur at low frequency. For example, in the Mefou Proposed National Park of Central Region Cameroon, only a single mature individual with one juvenile of one species of the genus, U. solheidii (De Wild.) Robyns \& Ghesq., was found in the course of many weeks of botanical surveys by numerous botanists collecting thousands of

PeerJ reviewing PDF | (2021:04:60715:1:1:NEW 27 Oct 2021) 
110 specimens (Cheek et al., 2011). However, in rare ecological circumstances, some species can 111 become locally dominant e.g., U. tripetala (Dennettia tripetala) in the understorey of maritime 112 lowland evergreen inselberg forest in Guinea (Couch et al., 2019), and also, U. congensis locally 113 subdominant in forests in western Uganda where it flowers synchronously and is dispersed by

\section{Materials \& Methods}

118

119

120

121

122

123

124

125

The electronic version of this article in Portable Document Format (PDF) will represent a published work according to the International Code of Nomenclature for algae, fungi, and plants (ICN), and hence the new names contained in the electronic version are effectively published under that Code from the electronic edition alone. In addition, new names contained in this work which have been issued with identifiers by IPNI will eventually be made available to the Global Names Index. The IPNI LSIDs can be resolved and the associated information viewed through any standard web browser by appending the LSID contained in this publication to the prefix "http://ipni.org/". The online version of this work is archived and available from the following digital repositories: PeerJ, PubMed Central, and CLOCKSS.

128

129

130

131

132

133

134

135

136

137

138

139

140

141

142

143

144

145

146

147

148

149

150

151

152

153

154

Fieldwork and specimen collection was as previously described in Cheek et al., (2021), under the same system of agreements, permits and approvals. The herbarium specimen was made using the Schweinfurth method, that is, initially preserved in ethanol until it could be dried in the standard way (Bridson \& Forman 1998) The first duplicate was deposited at YA, the remainder sent to $\mathrm{K}$ for identification and distribution following standard practice.

Herbarium citations follow Index Herbariorum (Thiers et al., continuously updated). Specimens were viewed at EA, K, P, WAG, and YA. The National Herbarium of Cameroon, YA, was searched for additional material of the new species, but without success. Images for specimens at WAG were studied at https://bioportal.naturalis.nl/?language=en and those from $\mathrm{P}$ at https://science.mnhn.fr/institution/mnhn/collection/p/item/search/form?lang=en_US. We also searched JSTOR Global Plants (https://plants.jstor.org/ accessed March 2021) for additional material, and finally the Global Biodiversity Facility (GBIF, www.gbif.org accessed March 2021). We compared our material with reference material of all other species in the genus. Binomial authorities follow the International Plant Names Index (IPNI 2021). The conservation assessment was made using the categories and criteria of IUCN (2012), adopting the $4 \mathrm{~km}^{2}$ cell-size preferred by IUCN. Since a single site is known for the species, it was not feasible to calculate a convex polygon for the extent of occurrence. Herbarium material was examined with a Leica Wild M8 dissecting binocular microscope fitted with an eyepiece graticule measuring in units of $0.025 \mathrm{~mm}$ at maximum magnification. The drawing was made with the same equipment using Leica 308700 camera lucida attachment. The botanical terms follow Beentje \& Cheek (2003), and format of the description follow the conventions of Kenfack et al., (2003) and Couvreur \& Luke (2010). The map was made using QGIS 3.12 (https://www.qgis.org).

\section{Results}

\section{Comparative morphology}


155 The new Uvariopsis dicaprio has leaves exceeding $15 \mathrm{~cm}$ long, cauliflorous flowers with 156 pedicels exceeding $10 \mathrm{~mm}$ long, petals free, exceeding $7 \mathrm{~mm}$ long, which grouped it with the other species of Uvariopsis in Cameroon (Couvreur et al. in press). Uvariopsis dicaprio is similar to $U$. solheidii by the flower buds conical that in U. dicaprio can vary from ovoid-conical to pyramidal. The two species can be separated using the differential characters in Table 1 below

However, based on morphology, Uvariopsis dicaprio is closely similar to two other Cameroonian species, $U$. korupensis and $U$. submontana. These four species, including $U$. solheidii, share the following features: they are all cauliflorous with well-developed $(1.5-8 \mathrm{~cm}$ or more long) pedicels, flowers which in bud are ovoid-conic, and more-or-less pyramidal (most strongly so in Uvariopsis dicaprio where the angles of the pyramid become wing-like: Fig. 1), petal shapes are more or less ovate-lanceolate, rather than orbicular as in most species of the genus. The four species can be compared and separated from each other using the characters in Table 1.

The petals of Uvariopsis dicaprio do not seem to reflex at anthesis exposing the staminal dome as they do in the other species, rather they open only slightly, concealing the staminal dome (Fig. 1). Moreover, the petals are only thinly leathery in texture, with an inner surface that is smooth, and not thick and fleshy with a tuberculate inner surface as in the other three species. Another difference is that the outer surface of the petals is mostly naked, with only a very few widely scattered hairs, not appressed-pubescent as in the other species (Fig. 3, Table 1). In leaf-blade dimensions Uvariopsis dicaprio fits within the ranges of those of most of the other species, and also in petal dimensions where it fits closest to the ranges of Uvariopsis korupensis and Uvariopsis submontana. Vegetatively Uvariopsis dicaprio differs from all three other species in having a much lower range of secondary nerves (5 to 8 ( -9$)$ versus 8 to 20 ), and can immediately be distinguished from them by having glabrous young stems, petioles and abaxial midribs (versus appressed pubescent or tomentose) (Table 1).

Uvariopsis dicaprio additionally has several features that appear unique in the genus that are presented in the notes section following the description below.

The new species can be separated from all other Cameroonian species of Uvariopsis using the key presented below, modified from Dagallier in Couvreur et al., (in press).

\section{Key to the species of Uvariopsis (and Dennettia) in Cameroon}
1. - Crushed leaves emitting a strong citrus scent ............................................... U. citrata
- Crushed leaves without citrus scent ........................................................................ 2
2. - Leaf blades $7.2-15.5(-18) \mathrm{cm}$ long; pedicel $0-7(-9) \mathrm{mm}$ long............................ 3
- Leaf blades $(11.1-) 16.3-38(-61.5) \mathrm{cm}$ long, pedicel $(3-) 8-60(-450) \mathrm{mm}$ long 6
3. - Flowers cauliflorous, pedicel $0-2 \mathrm{~mm}$ long ………………………..... U. sessiliflora
- Flowers ramiflorous, pedicel $(0-2)-3-11 \mathrm{~mm}$ long, sometimes cauliflorous ........... 4
4. - Flowers bisexual, petals $3(-4)$.................................................... Dennettia tripetala
- Flowers unisexual, petals 4 5


201

202

203

204

205

206

207

208

209

210

211

212

213

214

215

216

217

218

219

220

221

222

223

224

225

226

227

228

229

230

231

232

233

234

235

236

237

238

239

240

241

242

243

244

245

246

5. - Young branches glabrous or very sparsely pubescent, petals free .............. U. congensis

- Young branches densely to sparsely pubescent, petals basally fused ................ U. zenkeri

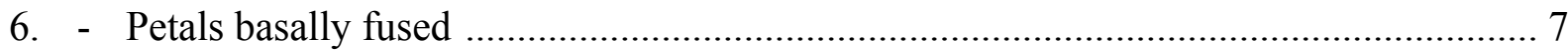

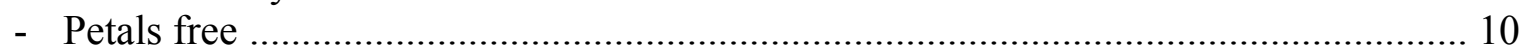

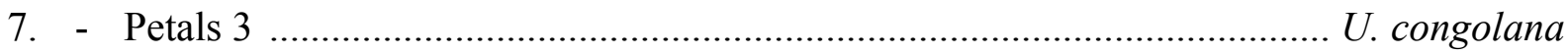

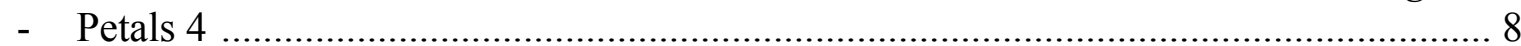

8. - Flower buds globose, monocarps verrucose …………………………... U. pedunculosa

- Flower buds conical to pyramidal, monocarps smooth .................................................. 9

9. - Sepals 5-10 $\mathrm{mm}$ long, flowers completely covering base of trunk, generally occurring above $800 \mathrm{~m}$ a.s.1. ............................................................................ Submontana

- Sepals 2-4 mm long, flowers partially covering base of trunk, generally occurring below $800 \mathrm{~m}$ a.s.1. ................................................................................... U. korupensis

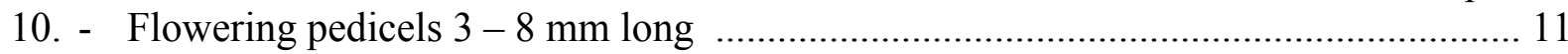

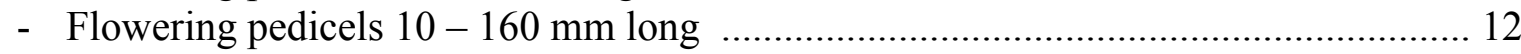

11. - Petals linear, 25 - $45 \mathrm{~mm}$ long, more than 6 times longer than wide ......... U. bakeriana

- Petals elliptic to ovate, $10-14 \mathrm{~mm}$ long, less than 6 times longer than wide ........... etugiana

12. - Flower buds globose U. dioica

- Flower buds conical or narrowly ovoid to pyramidal 13

13. - Stems and petioles tomentose, lateral nerves $8-13$ on each side of the midrib; flowers wine brown U. solheidii

- Stems and petioles glabrous; lateral nerves 5-8(-9) on each side of the midrib; flowers green-yellow U. dicaprio

Uvariopsis dicaprio Cheek \& Gosline sp. nov. Type: Cameroon, Littoral Region, Yabassi, Ebo Forest, 4 $4^{\circ} 20^{\prime} 44^{\prime \prime} \mathrm{N}, 10^{\circ} 24^{\prime} 33^{\prime \prime} \mathrm{E}, 849 \mathrm{~m}$ alt. Dicam Trail $2000 \mathrm{~m}$ from Bekob camp, male fl. 25 March 2008, MacKinnon 51 (holotype K001381842; isotypes MO, YA).

Syn. Uvariopsis ebo nom. nud. (Gosline et al,. 2021: 5).

Diagnosis. Similar to Uvariopsis solheidii (De Wild.) Robyns \& Ghesq., differing in the stem, petioles and abaxial midrib glabrous (versus tomentose); number of secondary nerves on each side of the midrib $5-8$ (versus $8-13$ ); petals yellow-green, (14-) $16 \times(5.5-) 9 \mathrm{~mm}$ (versus wine brown, $7-10 \times 2.5-5 \mathrm{~mm})$.

Cauliflorous, probably monoecious understorey tree $3-4 \mathrm{~m}$ tall. Trunk terete, lacking flutes or prop roots, $1.8-2.5 \mathrm{~cm}$ diameter at $1.5 \mathrm{~m}$ above the ground, bark smooth, dark-brown, with sparse, longitudinal lines of white lenticels (Fig. 1), the crown sparsely branched (Fig. 2). Leafy stems with $3-4$ leaves per season's growth, terete, internodes $(1.2-) 1.5-2.8(-4.3) \mathrm{cm}$ long, $0.15-0.2 \mathrm{~cm}$ diam., pale yellow-green, later orangish brown, glabrous. Axillary buds domeshaped $0.5-0.75 \times 1 \mathrm{~mm}$, bud-scales numerous, linear, spreading, densely hairy, hairs simple, appressed, c. $0.5 \mathrm{~mm}$ long, colourless or red brown. Leaves distichous, with punctations (minute translucent glands in the interior of the blade), lacking scent when crushed (collection metadata, 
247 MacKinnon 51), blades oblanceolate $17.7-20.2(-23) \times(6.4-) 7-7.9 \mathrm{~cm}$, acumen narrowly 248 triangular $(0.5-) 1-1.3 \mathrm{~cm}$ long, base broadly acute with convex edges, minutely cordate, blade 249 mounted above petiole, margins undulate-sinuous (live \& dried), midrib impressed on adaxial 250 surface, inconspicuous, below a groove; on abaxial surface subcylindrical, $1-1.2 \mathrm{~mm}$ diam., 251 conspicuous; secondary veins $5-8(-9)$ on each side of the midrib, brochidodromous, arising at 252 c. $50^{\circ}$ from the midrib, initially straight, then curving in the outer third, uniting with the secondary nerve above to form a looping inframarginal nerve, attaining $3-4 \mathrm{~mm}$ from the margin; intersecondary nerves sometimes present, tertiary nerves raised, conspicuous, forming a reticulum with cells $4-5 \mathrm{~mm}$ long, quaternary nerves inconspicuous; glabrous (except in bud when densely orange-brown hairy, hairs c. $0.1 \mathrm{~mm}$ long). Petiole stout, shallowly canaliculate, c. $4(-5) \mathrm{mm}$ long, $1.9-2.1 \mathrm{~mm}$ diam., narrowing at base and apex, adaxial groove shallow, c. 0.5 $\mathrm{mm}$ wide, glabrous. Female inflorescences unknown. Male inflorescences cauliflorous, scattered along the trunk from near ground level to the top of the trunk $2.5-3 \mathrm{~m}$ above the ground, each 1 - 7-flowered (Fig. 1 \& 2). Peduncles patent, c. 2 x $2 \mathrm{~mm}$, pale brown, glabrous, bearing subumbellate, radiating, 1-flowered partial-peduncles. Partial-peduncles $0.5-2 \times 0.9-1.2 \mathrm{~mm}$, terminating in $1-2$ bracts subtending a pedicel. Bracts oblong-elliptic, $1.5 \times 0.5-0.6 \mathrm{~mm}$, apex acute, outer surface about 50\% covered in appressed white hairs c. $0.15-0.2 \mathrm{~mm}$ long, inner surface glabrous. Male flowers. Pedicels $1.8-2.5 \mathrm{~cm}$ long, $0.1 \mathrm{~cm}$ diam., articulated with the partial-peduncle, with $(0-) 1(-2)$ scattered, bracteoles in the proximal few mm. Bracteoles similar to the bracts, ovate-oblong, shortly sheathing, $(1-) 1.25 \times 1 \mathrm{~mm}$, outer surface with sparse scattered simple appressed translucent hairs $0.05-0.2 \mathrm{~mm}$ long, buds narrowly ovoid to pyramidal, c. 16 x $11 \mathrm{~mm}$. Sepals 2, opposite, drying pale brown, reflexed, semi-orbicular, $1-1.5$ x $2.1-2.5 \mathrm{~mm}$, glabrous. Petals 4, uniseriate, free, thinly leathery, pale, glossy, yellow-green when live (Fig. 1), drying black, lanceolate-oblong, (14-) 16 x (5.5-) $9 \mathrm{~mm}$, not fleshy but c. $0.25-0.3 \mathrm{~mm}$ thick, apex rounded, base rounded, outer surface sparsely and inconspicuously hairy, hairs $7-9$ per $\mathrm{mm}^{2}$ ( $5 \%$ of surface covered), simple, translucent, appressed, c. $0.1 \mathrm{~mm}$ long, apices rounded. Inner surface of petals smooth, non-tuberculate, with a shallow ellipticoblong excavation c. $8 \times 5 \mathrm{~mm}$, the margin of the excavation raised, the apex with a ridge extending along the midline to the petal apex, glabrous apart from a few scattered erect, minute white hairs $0.05 \mathrm{~mm}$ long at the excavation apex. Staminal dome 3.5-4 mm long, 3.5-4 mm diam., consisting of stamens and a receptacular torus. Stamens shortly cylindrical-angular, c. 0.5 x $0.1(-0.2) \mathrm{mm}$, connective with two lateral extrorse longitudinal anther cells, each exceeding the connective. Apical connective appendage absent. Female flowers, fruit and seed unknown. Fig. $1-3$.

\section{DISTRIBUTION. Cameroon, (Fig. 4) endemic to the Ebo Forest of the Littoral Region on} present evidence.

HABITA T. Uvariopsis dicaprio is so far only known from lower submontane forest $(850 \mathrm{~m}$ elev.). below the elevation for the upper montane forest indicator species Podocarpus latifolius (Thunb.) R.Br. ex Mirb. The geology is ancient, highly weathered basement complex, with some ferralitic areas in foothill areas which are inland, c. $100 \mathrm{~km}$ from the coast. Altitude varies from c. $200 \mathrm{~m}$ to $1200 \mathrm{~m}$ elevation. The wet season (successive months with cumulative rainfall $>100$ $\mathrm{mm}$ ) falls between March and November and is colder than the dry season. Average annual rainfall at Bekob measured 2010 - 2016 is 2336 mm (Abwe, Ebo Forest Research Programme, Cameroon pers. comm., Abwe \& Morgan 2008, Cheek et al., 2018a). 
292 CONSERVATION STATUS. Uvariopsis dicaprio is currently known from a single specimen 293 with all male flowers at a single location inside the mid-eastern part of the Ebo Forest (Fig. 4). 294 Less than 50 mature individuals have been observed (Bethan Morgan pers. comm. to Cheek, 295 March 2021), despite the species being highly conspicuous in flower (Fig. 1) and situated on a 296 major footpath close to a research camp used by many biologists over the last 15 years.

297 Since 2006, botanical surveys have been mounted almost annually, at different seasons, over 298 many parts of the formerly proposed National Park of Ebo. About 2500 botanical herbarium 299 specimens have been collected, but this species has not yet been seen elsewhere in the c. 2000 $300 \mathrm{~km}^{2}$ of the Ebo Forest. However, the area outside the two research camps, especially the western 301 edge, has not been fully surveyed for plants. While it is likely that the species will be found at additional sites within the Ebo Forest, there is no doubt that it is genuinely range-restricted as are some other species of Uvariopsis in Cameroon (see introduction). Botanical surveys and other plant studies for conservation management in forest areas north, west and east of Ebo resulting in tens of thousands of specimens being collected and identified have failed to find any additional specimens of this species (Cheek et al., 1996; Cable \& Cheek 1998; Cheek et al., 2000; Maisels et al., 2000, Harvey et al., 2004; Cheek et al., 2004; Cheek et al., 2010; Harvey et al., 2010; Cheek et al., 2011).

The area of occupation of Uvariopsis dicaprio is estimated as $4 \mathrm{~km}^{2}$ using the IUCN preferred cell-size. The extent of occurrence is the same. In February 2020 it was discovered that moves were in place to convert the forest into two logging concessions (e.g. https://www.globalwildlife.org/blog/ebo-forest-a-stronghold-for-cameroons-wildlife/ and https://blog.resourceshark.com/cameroon-approves-logging-concession-that-will-destroy-eboforest-gorilla-habitat/ both accessed 12 April 2021). Such logging would result in timber extraction that would open up the canopy and remove the intact habitat in which Uvariopsis dicaprio is found. Additionally, slash and burn agriculture often follows logging trails and would negatively impact the population of this species. Fortunately the logging concession was suspended in August 2020 due to representations to the President of Cameroon on the global importance of the biodiversity of Ebo (https://www.businesswire.com/news/home/20200817005135/en/Relief-in-the-ForestCameroonian-Government-Backtracks-on-the-Ebo-Forest accessed 12 April 2021). However, the forest habitat of this species remains unprotected and threats of logging and conversion of the habitat to plantations remain, and mining is also a threat. Uvariopsis dicaprio is therefore here assessed as Critically Endangered, CR B1+2ab(iii), D.

PHENOLOGY. Flowering has been observed in late March and early April (Bethan Morgan pers. comm. 2021).

ETYMOLOGY. This threatened and spectacular tree is named for the American actor and conservationist Leonardo DiCaprio, who, through several months in 2020, lobbied extensively on social media (e.g. https://www.instagram.com/p/B_0LSAhFRue/?hl=en ; https://twitter.com/leodicaprio/status/1257729388314943490?lang=en both accessed 12 April 2021) to draw attention to threats for the numerous rare Ebo species from the logging concession that had been announced at Ebo earlier that year. The concession was cancelled in August 2020, surely partly due to his efforts.

VERNACULAR NAMES \& USES. None are known.

NOTES.. The distal half of the petals and the margins of the proximal half are flat, wing-like and held against each other (applanate) in bud. In section therefore, the distal part of the corolla will 
338

339

340

341

342

343

344

345

346

347

348

349

350

351

352

353

354

355

356

357

358

359

360

361

362

363

364

365

366

367

368

369

370

371

372

373

374

375

376

377

378

379

380

381

382

383

appear cross-shaped (see Fig. 1). This seems to be an extreme form of the petal structure and pyramidal flower bud shape seen in the probably closely related Cameroonian species Uvariopsis korupenis and U. submontana (see results, above). Uvariopsis dicaprio is further distinct from all other species of the genus in that a distinct peduncle is present that bears several branches (partial-peduncles) each of which bears and is articulated with a single pedicel (Fig. 3). Other cauliflorous species of Uvariopsis have few to many-flowered fasciculate inflorescences, a peduncle not being observed, the pedicels arising directly from a perennial woody burr. In noncauliflorous species of Uvariopsis the inflorescences consist of a single, axillary flower. It was first intended to name Uvariopsis dicaprio as $U$. ebo and this name was used in the bioRxiv pre-print (Gosline et al,. 2021: 5). However, such pre-prints have no standing as publications for nomenclatural purposes according to the Code (Turland et al. 2018) because they not intended by the authors as the final publication. Therefore Uvariopsis ebo is classed as a nominum nudum.

\section{Discussion}

\section{Pollination biology in Uvariopsis and Uvariopsis dicaprio.}

Unusual and distinctive features of Uvariopsis dicaprio within the genus include the colour, shape and texture of the corolla. Bright, glossy, pale yellow-green petals are otherwise unknown in a genus where the petals are otherwise dull shades of pink to purple and brown. Unlike in all other species of the genus known, the petals are not thick and fleshy but thinly leathery. The centre of the proximal half of each petal is concave before anthesis, forming a globose chamber for the staminal dome with the other three petals (Fig. 1). On the inner surface of the petal, the concave area is demarcated by an inverted U-shaped, distinct, raised, broad ridge which seems to be the point of contact with those of the other sepals, sealing the chamber. Such a structure has not been reported or observed in other species of the genus.

A striking feature of Uvariopsis dicaprio is the presentation and colour of the flowers. Of the 14 species of the genus in Cameroon, 11 are cauliflorous. All of these except $U$. dicaprio have petals which are shades of pink, red, purple to brown. Cauliflorous Uvariopsis species present their flowers more or less perpendicular to the trunk; the flowers of $U$. dicaprio are pendant and with the corolla opening only slightly (see results), and facing the ground (Fig. 1). All species of Uvariopsis other than U. bisexualis Verdc. are monoecious. The majority of Annonaceae species are protogynous hermaphrodites, most often beetle pollinated, some exhibiting thermogenesis (Gottsberger, 2012). In the monoecious U. bakeriana (Hutch. \& Dalziel) Robyns \& Ghesq. and U. congolana (De Wild.) R.E.Fr. the female flowers mature before the male (Gottsberger, Meinke \& Porembski, 2011), and our evidence for U. dicaprio suggests the same sequence. In U. submontana, U. korupensis, U. congolana, U. dioica, and U. pedunculosa, the male flowers are higher on the trunk, with the female flowers clustered towards the base of the trunk. In $U$. dioica and $U$. korupensis the female pedicels are generally less than $10 \mathrm{~cm}$ long and in $U$. korupensis the fleshy fruits mature in dense concentrations at the base of the trunk where they can attract ground-dwelling animals.

In Uvariopsis congolana,(Diels) Robyns \& Ghesq. and U. pedunculosa (Diels) Robyns \& Ghesq. the female globular flowers are born on slender pedicels to c. $50 \mathrm{~cm}$ long embedded in the leaf litter. This habit is also exhibited by Isolona cauliflora Verdc. Gottsberger, Meinke \& Porembski (2011) studied the visitors to U. pedunculosa (identified as U. congolana) and concluded that pollination likely was by small litter-flies (not beetles). "It is suspected that this

PeerJ reviewing PDF | (2021:04:60715:1:1:NEW 27 Oct 2021) 
384

385

386

387

388

389

390

391

392

393

394

395

396

397

398

399

400

401

402

403

404

405

406

407

408

409

410

411

412

413

414

415

416

417

418

419

420

421

422

423

424

425

426

427

428

429

predominantly sapromyiophilous species has a pollination system mimicking fungi and/or carcass, and that the pollinating flies normally live on fungi and/or carcass." They also conclude that $U$. bakeriana is pollinated by dung-flies. Mertens et al., (2018) studied U. dioica and found minimal visitation by Lepidoptera but more by nocturnal crickets and cockroaches. In all three species of Uvariopsis where pollination studies have been done, the researchers have described the pollinators as scarce and unpredictable, and thermogenesis has not been observed.

In this context, it seems likely that $U$. dicaprio has found a different pollinator from its sister taxa. The bright pale yellow-green flowers suggest nocturnal pollinators. The similarly glossy, yellow-green flowers of the Asian, widely cultivated ylang-ylang, Cananga odorata (Lam.) Hook.f. \& Thomson are pollinated by nocturnal moths and small beetles (Parrotta, 2014). We speculate that the flowers of Uvariopsis dicaprio, unique in the genus, may also be adaptated for moth pollination, otherwise unrecorded in indigenous African Annonacaeae (Gottsberger 2012). Concerted field monitoring to observe pollinators is needed during the flowering season of Uvariopsis dicaprio to test this hypothesis.

\section{The centre of diversity of Uvariopsis}

With the recognition in this paper of Uvariopsis dicaprio, 20 species are now accepted in Uvariopsis (see introduction). The highest species diversity for any country is found in Cameroon, now with 14 species, and with six of these nationally endemic. However, the biogeographic area with highest species diversity is the much smaller area of the Cross-Sanaga Interval which includes 12 species, of which five are globally endemic including Uvariopsis dicaprio. The Cross-Sanaga Interval appears to be the main centre of diversity of Uvariopsis. Numerous other plant genera have their centre of diversity in the interval (Cheek et al., 2001) and some are endemic to it, e.g. Medusandra Brenan (Peridiscaceae formerly Medusandraceae, Breteler et al., (2015), Soltis et al., (2007)). The fleshy orange-red fruits of Uvariopsis are consumed by primates, which are thought to disperse their seeds (Dominy \& Duncan, 2005). The high level of endemism of Uvariopsis species to the Cross River Interval may therefore be linked to the high number of primate species that are also endemic to the interval, bounded by the rivers Cross and Sanaga that represent barriers to primates. Ten species of primate are confined to the Interval (Kingdon 2015).

\section{The range of Uvariopsis dicaprio and other endemic species in the Ebo Forest area.} Abwe \& Morgan, (2008) and Cheek et al. (2018a) give overviews of habitats, species and the importance for conservation of the highly threatened Ebo Forest to which Uvariopsis dicaprio is restricted on current evidence. Sixty-eight globally threatened plant species are currently listed from Ebo on the IUCN Red List website (iucnredlist.org/ accessed 12 April 2021) and the number is set to rise rapidly as more of Cameroon's rare species are assessed for their conservation status as part of the Cameroon TIPAs programme. The discovery of a new species to science at the Ebo Forest is not unusual. Numerous new plant species have been published from Ebo in recent years. Examples of other species that, like Uvariopsis dicaprio, appear to be strictly endemic to the Ebo area on current evidence are presented in Table 2:

With the exception of Crateranthus cameroonensis Cheek \& Prance which is widespread over a large part of eastern Ebo, each of the eight species listed have on current evidence, a single small discreet range of no more than $8 \mathrm{~km}^{2}$ (usually far smaller) within the Ebo Forest area (see the references cited in Table 2). These species are not concentrated together in one or several spots 
430 but are scattered from the far West to the East of the forest, none of the species, apart from the 431 Crateranthus, sympatric with any of the others.

432

433

434

435

436

437

438

439

440

441

442

443

444

445

446

447

448

449

450

451

452

453

454

455

456

457

458

459

460

461

462

463

464

465

466

467

468

469

470

471

472

473

474

Further species described from Ebo have proved not to be endemic but to have also been found further west, in the Cameroon Highlands, particularly at Mt Kupe and the Bakossi Mts (Cheek et al., 2004). Examples are Gilbertiodendron ebo Burgt \& Mackinder, Myrianthus fosi Cheek (Harvey et al., 2010), Salacia nigra Cheek (Gosline \& Cheek 2014) and Talbotiella ebo Mackinder \& Wieringa (Mackinder et al., 2010).

Additionally, several species initially thought endemic to Mt Kupe and the Bakossi Mts and adjoining areas in the Cameroon Highlands have subsequently been found at Ebo, e.g. Coffea montekupensis Stoff. (Stoffelen et al., 1997), Costus kupensis Maas \& H. Maas (Maas-van der Kamer et al., 2016), Deinbollia oreophila Cheek (Cheek \& Etuge 2009), Microcos magnifica Cheek (Cheek 2017), and Uvariopsis submontana Kenfack, Gosline \& Gereau (Kenfack et al., 2003). It is considered likely that additional Kupe species may yet be found at Ebo such as Brachystephanus kupeensis I.Darbysh. (Champluvier \& Darbyshire 2009), and Impatiens frithii Cheek (Cheek \& Csiba 2002) since new discoveries are still frequently being made in the Ebo Forest. Therefore, it is possible that Uvariopsis dicaprio might yet also be found in the Cameroon highlands, e.g., at Mt Kupe. However, this is thought to be only a relatively small possibility given the high level of survey effort at Mt Kupe: if it occurred there, it is highly likely that it would have been recorded already since it is so spectacular when in flower that it would be difficult to overlook.

\section{Conclusions}

Such discoveries as this new species underline the urgency for making further such discoveries while it is still possible since in all but one of the cases given above, the species have very narrow geographic ranges and/or very few individuals, and face threats to their natural habitat, putting these species at high risk of extinction.

About 2000 new species of vascular plant have been discovered each year for the last decade or more. Until species are known to science, they cannot be assessed for their conservation status and the possibility of protecting them is reduced (Cheek et al., 2020). Documented extinctions of plant species are increasing, e.g. Oxygyne triandra Schltr. and Afrothismia pachyantha Schltr. of South West Region, Cameroon are now known to be globally extinct (Cheek \& Williams 1999, Cheek et al., 2018c, Cheek et al., 2019). In some cases, species appear to be extinct even before they are known to science, such as Vepris bali Cheek, also from the Cross-Sanaga interval in Cameroon (Cheek et al., 2018d) and elsewhere, Nepenthes maximoides Cheek (King \& Cheek, 2020). Most of the 815 Cameroonian species in the Red Data Book for the plants of Cameroon are threatened with extinction due to habitat clearance or degradation, especially of forest for small-holder and plantation agriculture following logging (Onana \& Cheek, 2011). Efforts are now being made to delimit the highest priority areas in Cameroon for plant conservation as Tropical Important Plant Areas (TIPAs) using the revised IPA criteria set out in Darbyshire et al., (2017). This is intended to help avoid the global extinction of additional endemic species such as Uvariopsis dicaprio which will be included in the proposed Ebo Forest IPA. With only one locality known, Uvariopsis dicaprio represents another narrowly endemic Cameroonian species threatened with extinction due to deforestation for oil palm plantations,

PeerJ reviewing PDF | (2021:04:60715:1:1:NEW 27 Oct 2021) 
475 small-scale agriculture, mining and logging, widespread threats posing extinction risks to plant 476 species in Cameroon (Onana \& Cheek 2011, Cheek et al., 2018a).

477

478

479

480

481

482

483

484

485

486

487

488

489

490

491

492

493

494

495

496

497

498

499

500

501

502

503

504

505

506

507

508

509

510

\section{Acknowledgements}

This paper was completed as part of the Cameroon TIPAs (Tropical Important Plant Areas) project at RBG, Kew, which is supported by Players of People's Postcode Lottery. Formal redlisting of this species will be supported by the John S. Cohen Foundation. Ekwoge Abwe and Bethan Morgan and their team at the Ebo Forest programme are thanked hugely for making available the specimen and photos on which this paper is based and for expediting our botanical surveys in the Ebo Forest of Cameroon over several years which allowed us to give context about the Ebo Forest in this paper. San Diego Zoo Wildlife Alliance are thanked for facilitating use of the photos. We thank Janis Shillito for typing the manuscript and Megan Griffiths for drawing Figure 3. The heads of IRAD (Institute of Research in Agronomic Development)National Herbarium of Cameroon, Yaoundé, successively Jean-Michel Onana, Florence Ngo Ngwe, Eric Nana and Jean Betti Lagarde, are thanked for co-ordinating the co-operation with the Royal Botanic Gardens, Kew. The authors would like to thank anonymous reviewers for comments on an earlier version of this manuscript.

\section{References}

Abwe EE, Morgan BJ. 2008. The Ebo Forest: four years of preliminary research and conservation of the Nigeria-Cameroon chimpanzee (Pan troglodytes vellerosus). Pan Africa News 15: 26-29. DOI: 10.5134/143494.

Alvarez MG, Cheek M, Sonké B._2021. Kupeantha yabassi (Coffeeae-Rubiaceae), a new Critically Endangered shrub species of the Ebo Forest area, Littoral Region, Cameroon. Kew Bulletin. In press.

Barthlott W, Lauer W, Placke A. 1996. Global distribution of species diversity in vascular plants: towards a world map of phytodiversity. Erkunde 50: 317-328.

Beentje H, Cheek M. 2003. Glossary. Balkema, Lisse, Netherlands.

Breteler FJ, Bakker FT \& Jongkind CC. 2015. A synopsis of Soyauxia (Peridiscaceae, formerly Medusandraceae) with a new species from Liberia. Plant Ecology and Evolution. 148(3), $409-$ 419. https://doi.org/10.5091/plecevo.2015.1040

Bridson DM, Forman L. 1998. Herbarium handbook. Richmond: Royal Botanic Gardens, Kew.

Cable S, Cheek M. 1998. The Plants of Mt Cameroon, a Conservation Checklist. Richmond: Royal Botanic Gardens, Kew. 
511 Champluvier D, Darbyshire I. 2009. revision of the genera Brachystephanus and Oreacanthus 512 (Acanthaceae) in tropical Africa. Systematics and Geography of Plants 79: 115-192. DOI:

$513 \quad 10.2307 / 25746$.

514 Chatrou LW, Pirie MD, Erkens RH, Couvreur TL, Neubig KM, Abbott JR, Mols JB, Maas JW, 515 Saunders RM, Chase MW. 2012. A new subfamilial and tribal classification of the pantropical 516 flowering plant family Annonaceae informed by molecular phylogenetics. Botanical Journal of 517 the Linnean Society. 169(1): 5-40.

518 Cheek M. 2017. Microcos magnifica (Sparrmanniaceae) a new species of cloud forest tree from 519 Cameroon. DOI: 10.7717/peerj.4137.

520 Cheek M, Achoundong G, Onana J-M, Pollard B, Gosline G, Moat J, Harvey YB. 2006.

521 Conservation of the Plant Diversity of Western Cameroon. In: Ghazanfar SA, H.J. eds.

522 Proceedings of the 17th AETFAT Congress, Addis Ababa. Ethiopia, 779-791.

523 Cheek M, Alvarez-Aguirre MG, Grall A, Sonké, B, Howes MJR, Larridon I. 2018b. Kupeantha 524 (Coffeeae, Rubiaceae), a new genus from Cameroon and Equatorial Guinea. PLoS ONE 13: 525 0199324. DOI: 10.1371/journal.pone.0199324.

526 Cheek M, Cable S, Hepper FN, Ndam N, Watts J. 1996. Mapping plant biodiversity on Mt. In:

527 Maesen, Burgt, Rooy eds. The Biodiversity of African Plants (Proceedings XIV AETFAT

528 Congress. Cameroon: Kluwer, 110-120. DOI: 10.1007/978-94-009-0285-5_16.

529 Cheek M, Csiba L. 2002. A new epiphytic species of Impatiens (Balsaminaceae) from western 530 Cameroon. Kew Bulletin 57: 669-674. DOI: 10.2307/4110997.

531 Cheek M, Etuge M. 2009. A new submontane species of Deinbollia (Sapindaceae) from Western 532 Cameroon and adjoining Nigeria. Kew Bulletin 64: 503-508. DOI: 10.1007/s12225-009-9132-4.

533 Cheek M, Etuge M, Williams S. 2019. Afrothismia kupensis sp. nov. (Thismiaceae), Critically 534 Endangered, with observations on its pollination and notes on the endemics of Mt Kupe,

535 Cameroon. Blumea - Biodiversity, Evolution and Biogeography of Plants 64: 158-164.

536 Cheek M, Feika A, Lebbie A, Goyder D, Tchiengue B, Sene O, Tchouto P, Burgt X. 2017. A 537 synoptic revision of Inversodicraea (Podostemaceae. Blumea 62: 125-156. DOI:

538 10.3767/blumea.2017.62.02.07.

539 Cheek M, Gosline G, Onana J-M. 2018d. Vepris bali (Rutaceae), a new critically endangered 540 (possibly extinct) cloud forest tree species from Bali Ngemba, Cameroon. Willdenowia 48: 285541 292. DOI: $10.3372 /$ wi.48.48207. 
542 Cheek M, Harvey YB, Onana J-M. 2010. The Plants of Dom. Bamenda Highlands, Cameroon: A

543 Conservation Checklist. Richmond: Royal Botanic Gardens, Kew.Cheek M, Harvey Y, Onana J-

544 M. 2011. The Plants of Mefou Proposed National Park. Yaoundé, Cameroon: A Conservation

545 Checklist. Richmond: Royal Botanic Gardens, Kew.

546 Cheek M, Luke WRQ, Gosline G. 2021a. Lukea gen. nov. (Monodoreae-Annonaceae) with two

547 new threatened species of shrub from the forests of the Udzungwas, Tanzania \& Kaya Ribe,

548 Kenya. bioRxiv (pre-print). https://doi.org/10.1101/2021.05.14.444227

549 Cheek M, Mackinder B, Gosline G, Onana J-M, Achoundong G. 2001. The phytogeography and

550 flora of western Cameroon and the Cross River-Sanaga River interval. Systematics and

551 Geography of Plants 71: 1097-1100. DOI: 10.2307/3668742.

552 Cheek M, Nic Lughadha E, Kirk P, Lindon H, Carretero J, Looney B, Douglas B, Haelewaters 553 D, Gaya E, Llewellyn T, Ainsworth M, Gafforov Y, Hyde K, Crous P, Hughes M, Walker BE, 554 Forzza RC, Wong KM, Niskanen T. 2020. New scientific discoveries: plants and fungi. Plants, 555 People Planet 2: 388. DOI: 10.1002/ppp3.10148.

556 Cheek M, Onana JM, Chapman HM. 2021. The montane trees of the Cameroon Highlands, 557 West-Central Africa, with Deinbollia onanae sp. nov. (Sapindaceae), a new primate-dispersed, 558 Endangered species. PeerJ 9:e11036 https://doi.org/10.7717/peerj.11036

559

560 Cheek M, Onana J-M, Pollard BJ. 2000. The Plants of Mount Oku and the Ijim Ridge,

561 Cameroon, a Conservation Checklist. Kew: Royal Botanic Gardens, Kew.

562 Cheek M, Pollard BJ, Darbyshire I, Onana J-M, Wild C. 2004. The Plants of Kupe, Mwanenguba 563 and the Bakossi Mountains. Cameroon: A Conservation Checklist. Richmond: Royal Botanic 564 Gardens, Kew.

565 Cheek M, Prenner G, Tchiengué B, Faden RB. 2018a. Notes on the endemic plant species of the 566 Ebo Forest, Cameroon, and the new, Critically Endangered, Palisota ebo (Commelinaceae. Plant 567 Ecology \& Evolution 151: 434-441. DOI: 10.5091/plecevo.2018.1503.

568 Cheek M, Tchiengué B, van der Burgt X. 2021b. Taxonomic revision of the threatened African 569 genus Pseudohydrosme Engl. DOI: 10.7717/peerj.10689.

570 Cheek M, Tsukaya H, Rudall PJ, Suetsugu K. 2018c. Taxonomic monograph of Oxygyne

571 (Thismiaceae), rare achlorophyllous mycoheterotrophs with strongly disjunct distribution.

572 Cheek M, Williams S. 1999. A Review of African Saprophytic Flowering Plants. In: Timberlake, 573 Kativu eds. African Plants. Biodiversity, Taxonomy \& Uses. Proceedings of the 15th AETFAT 574 Congress at Harare. Zimbabwe, 39-49. 
575 Cheek M, Xanthos M. 2012. Ardisia ebo sp. nov. (Myrsinaceae), a creeping forest subshrub of 576 Cameroon and Gabon. Kew Bull 67: 281-284. DOI: 10.1007/s12225-012-9362-8.

577 Couch C, Cheek M, Haba PM, Molmou D, Williams J, Magassouba S, Doumbouya S, Diallo 578 YM. 2019. Threatened habitats and Important Plant Areas (TIPAs) of Guinea, west Africa. 579 Royal Botanic Gardens, Kew. London.

580 Couvreur TLP, Dagallier L-PMJ, Crozier F, Ghogue J-P, Hoekstra PH, Kamdem NG, Johnson 581 DM, Murray N, Sonké B.. in press. Flora of Cameroon - Annonaceae. Phytokeys

582 Couvreur TL, Luke WRQ. 2010. A new species of Uvariopsis (Annonaceae), endemic to the 583 Eastern Arc Mountains of Tanzania. Blumea-Biodiversity, Evolution and Biogeography of Plants 584 55: 68-72.

585 Couvreur TL, Niangadouma R. 2016. New species of Uvariopsis (Annonaceae) and 586 Laccosperma (Arecaceae/Palmae) from Monts de Cristal, Gabon. PhytoKeys 1:8.

587 Dagallier LP, Janssens SB, Dauby G, Blach-Overgaard A, Mackinder BA, Droissart V, Svenning 588 JC, Sosef MS, Stévart T, Harris DJ, Sonké B. 2020. Cradles and museums of generic plant 589 diversity across tropical Africa. New Phytologist 225(5):2196-213.

590 Darbyshire I, Anderson S, Asatryan A, Byfield A, Cheek M, Clubbe C, Ghrabi Z, Harris T, 591 Heatubun CD, Kalema J, Magassouba S, McCarthy B, Milliken W, Montmollin B de, Nic 592 Lughadha E, Onana JM, Saidou D, Sarbu A, Shrestha K, Radford EA. 2017. Important Plant 593 Areas: revised selection criteria for a global approach to plant conservation. Biodiversity 594 Conservation 26:1767-1800. DOI: 10.1007/s10531-017-1336-6.

595 Dominy NJ, Duncan BW. 2005. Seed-spitting Primates and the Conservation and Dispersion of 596 Large-seeded Trees. International Journal of Primatology 26:631-649. DOI: 10.1007/s10764597 005-4370-2.

598 Gereau RE, Kenfack D. 2000. Le genre Uvariopsis (Annonaceae) en Afrique tropicale, avec la 599 description d'une espèce nouvelle du Cameroun. Adansonia ser. 3, 22: 39-43.

600 Gosline G, Cheek M, Kami T. 2014. Two new African species of Salacia (Salacioideae, 601 Celastraceae. Blumea 59:26-32. DOI: 10.3767/000651914x682026.

602 Gosline G, Cheek M, Onana J-M, Ngansop E, van der Burgt X, Dagallier L-PJM. 2021.

603 Uvariopsis ebo (Annonaceae) a new, Critically Endangered tree species from the Ebo Forest, Cameroon 604 and a key to the Cameroonian species of Uvariopsis. BioRxiv (pre-print)

605 DOI: https://doi.org/10.1101/2021.03.26.437154

606 Gottsberger G, Meinke S, Porembski S. 2011. First records of flower biology and pollination in 607 African Annonaceae: Isolona, Piptostigma, Uvariodendron, Monodora and Uvariopsis. Flora- 
608 Morphology, Distribution, Functional Ecology of Plants 206:498-510. DOI:

609 10.1016/j.flora.2010.08.005.

610 Gottsberger G. 2012. How diverse are Annonaceae with regard to pollination? Botanical Journal 611 of the Linnean Society 169:245-261. DOI: 10.1111/j.1095-8339.2011.01209.x.

612 Guo X, Tang CC, Thomas DC, Couvreur TL, Saunders RM. 2017. A mega-phylogeny of the 613 Annonaceae: taxonomic placement of five enigmatic genera and support for a new tribe, 614 Phoenicantheae. Scientific Reports. 7(1):1-1.

615 Harvey YB, Pollard BJ, Darbyshire I, Onana J-M, Cheek M. 2004. The Plants of Bali Ngemba 616 Forest Reserve. Cameroon: A Conservation Checklist. Richmond: Royal Botanic Gardens, Kew.

617 Harvey YB, Tchiengue B, Cheek M. 2010. The plants of the Lebialem Highlands, a conservation 618 checklist. Richmond: Royal Botanic Gardens, Kew.

619 IPNI continually updated. The International Plant Names Index. The Royal Botanic Gardens, Kew,

620 Harvard University Herbaria \& Libraries and Australian National Botanic Gardens. Available at 621 http://www.ipni.org (accessed 29 April 2021).

622 IUCN 2012. IUCN red list categories: Version 3.1. Gland, Switzerland and Cambridge, U.K: 623 IUCN Species Survival Commission.

624 Kamer H, Maas PJM, Wieringa JJ, Specht CD. 2016. Monograph of African Costus. Blumea 625 Biodiversity, Evolution and Biogeography of Plants 61: 280-318. DOI:

$626 \quad 10.3767 / 000651916$ X694445.

627 Kenfack D, Gosline G, Gereau RE, Schatz G. 2003. The genus Uvariopsis in Tropical Africa, 628 with a recombination and one new species from Cameroon. Novon 13: 443-449. DOI:

$629 \quad 10.2307 / 3393377$

630 King C, Cheek M. 2020. Nepenthes maximoides (Nepenthaceae) a new, critically endangered 631 (possibly extinct) species in species Sect. Alatae from Luzon, Philippines showing striking 632 pitcher convergence with N. maxima (Sect. Regiae) of Indonesia. DOI: 10.7717/peerj.9899.

633 Kingdon J. 2015. The Kingdon field guide to African mammals. Bloomsbury Publishing.

634 Mackinder BA, Wieringa JJ, Burgt XM. 2010. A revision of the genus Talbotiella Baker $\mathrm{f}$. 635 (Caesalpinioideae: Leguminosae). Kew Bulletin 65: 401-420. DOI: 10.1007/s12225-010-9217-0.

636 Maisels FM, Cheek M, Wild C. 2000. Rare plants on Mt Oku summit, Cameroon. Oryx 34: 136637 140. DOI: 10.1017/s0030605300031057. 
638 Mertens J, Tropek R, Foryuy F, Maicher V, Janeček S. 2018. Communities of flower visitors of 639 Uvariopsis dioica (Annonaceae) in lowland forests of Mt. Cameroon, with notes on its potential 640 pollinators. African Journal of Ecology 56:146-152. DOI: $10.1111 /$ aje.12429

641 Onana J-M. 2011. The vascular plants of Cameroon, a taxonomic checklist with IUCN

642 Assessments. Richmond: Royal Botanic Gardens, Kew.

643 Onana J-M, Cheek M. 2011. Red data book of the flowering plants of Cameroon, IUCN global 644 assessments. Richmond: Royal Botanic Gardens, Kew.

645 Parrotta JA. 2014. Cananga odorata, in Roloff A, Weisgerber H, Lang UM, Stimm B, Schütt P. 646 (eds). Enzyklopädie der Holzgewächse: Handbuch und Atlas der Dendrologie. Wiley-VCH 647 Verlag GmbH \& Co.

648 Prance GT, Jongkind CCH. 2015. A revision of African Lecythidaceae. Kew Bulletin 70: 6: 13. 649 DOI: $10.1007 / \mathrm{s} 12225-014-9547-4$.

650 Soltis DE, Clayton JW, Davis CC, Wurdack KJ, Gitzendanner MA, Cheek M, Savolainen V, 651 Amorim AM, Soltis PS. 2007. Monophyly and relationships of the enigmatic family

652 Peridiscaceae. Taxon 56: 65-73.

653 Sosef MSM, Wieringa JJ, Jongkind CCH, Achoundong G, Azizet Issembé Y, Bedigian D, Van 654 Den Berg RG, Breteler FJ, Cheek M, Degreef J. 2005. Checklist of Gabonese Vascular Plants. 655 Scripta Botanica Belgica 35.

656 Stoffelen P, Cheek M, Bridson D, Robbrecht E. 1997. A new species of Coffea (Rubiaceae) and 657 notes on Mt Kupe (Cameroon. Kew Bulletin 52: 989-994. DOI: 10.2307/3668527.

658 Thiers B. continuously updated. Index Herbariorum: A global directory of public herbaria and 659 associated staff. New York Botanical Garden's Virtual Herbarium. Available at 660 http://sweetgum.nybg.org/ih/ (accessed June 2021).

661

662 Turland NJ, Wiersema JH, Barrie FR, Greuter W, Hawksworth DL, Herendeen PS, Knapp S, 663 Kusber W-H, Li D-Z, Marhold K, May TW, McNeill J, Monro AM, Prado J. Price MJ, Smith 664 GF. (ed.) 2018. International Code of Nomenclature for algae, fungi, and plants (Shenzhen 665 Code) adopted by the Nineteenth International Botanical Congress Shenzhen, China, July 2017.666 Glashütten: Koeltz Botanical Books. [= Regnum Veg. 159].

667

668 van Heusden ECH. 1992. Flowers of Annonaceae: morphology, classification, and evolution. 669 Blumea Supplement 7: 1-218.

670 
Figure 1

Uvariopsis dicaprio.

Cauliflorous inflorescences on trunk. Photo Lorna MacKinnon.

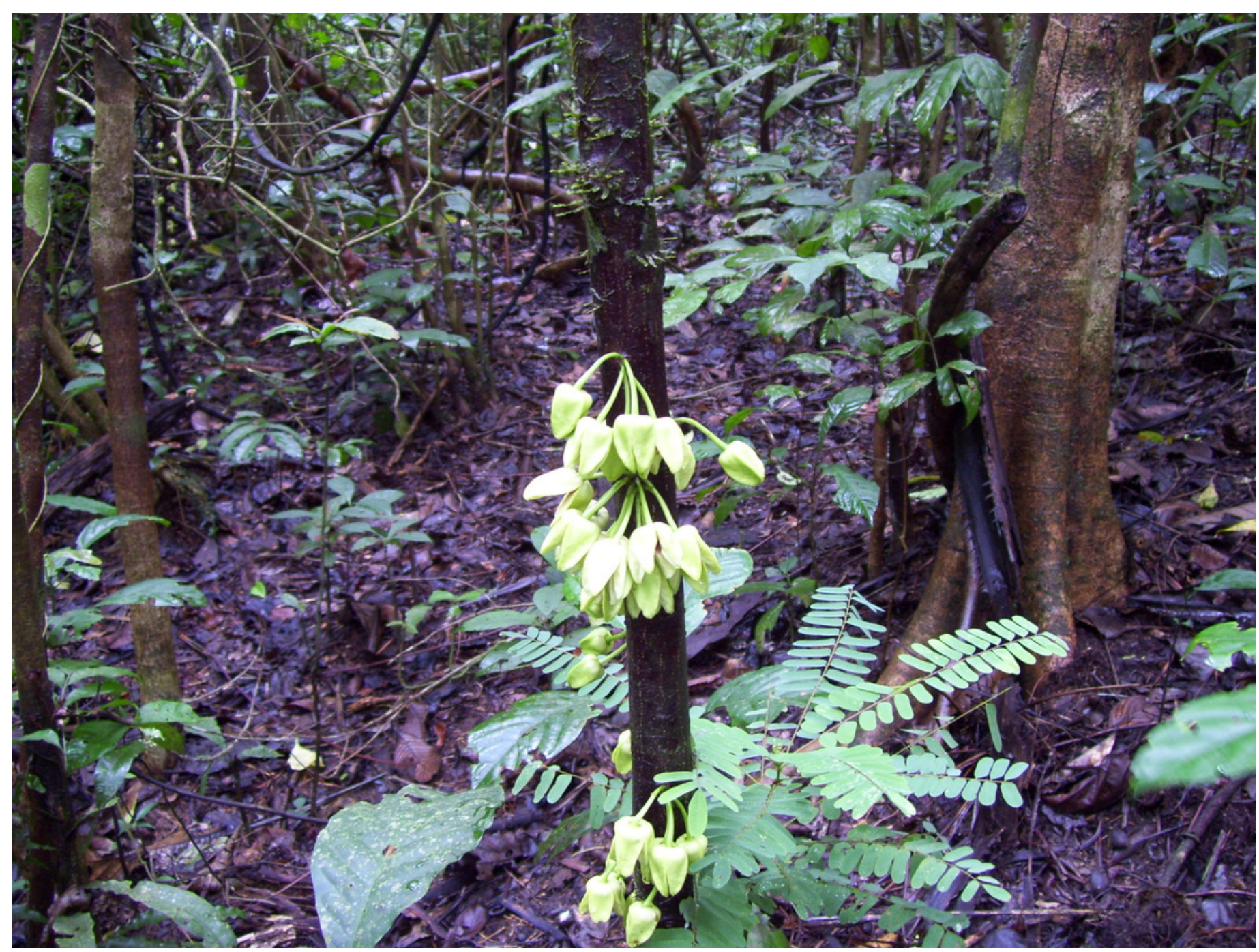


Figure 2

\section{Uvariopsis dicaprio}

Trunk apex with cauliflorous flowers and canopy. Photo Lorna MacKinnon.

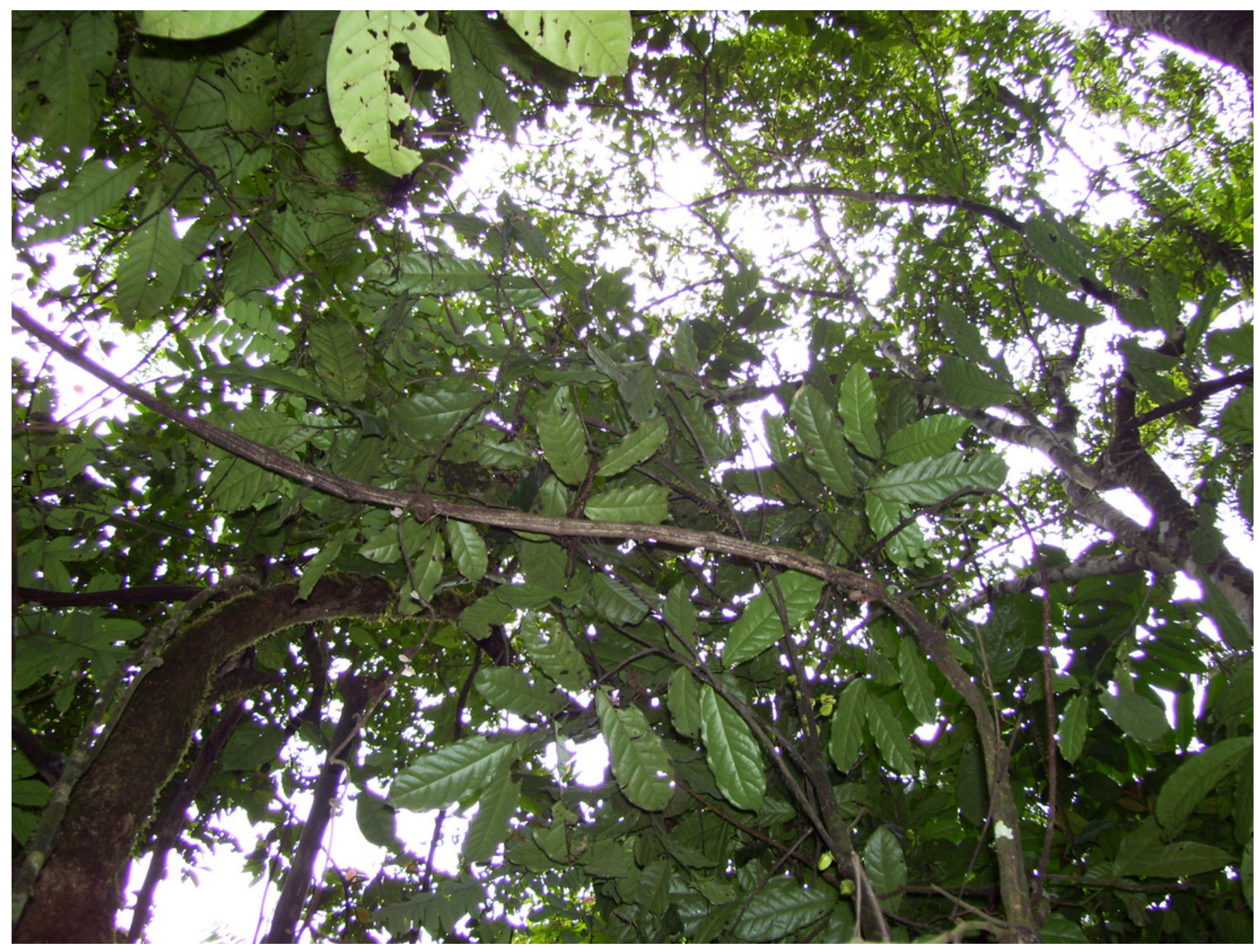




\section{Figure 3}

Uvariopsis dicaprio

A habit, cauliflorous inflorescences on trunk; B leafy branch, one season's growth; C inflorescence, showing pedicel articulations, bracts and bracteoles; D flowers, with one petal folded back to show the staminal dome; $\mathbf{E}$ detail of sparse hairs on abaxial petal surface; $\mathbf{F}$ stamen, side view; G junction of base of leaf with stem, showing dome-like axillary bud. All drawn from MacKinnon 51 (K) by MEG GRIFFITHS. 

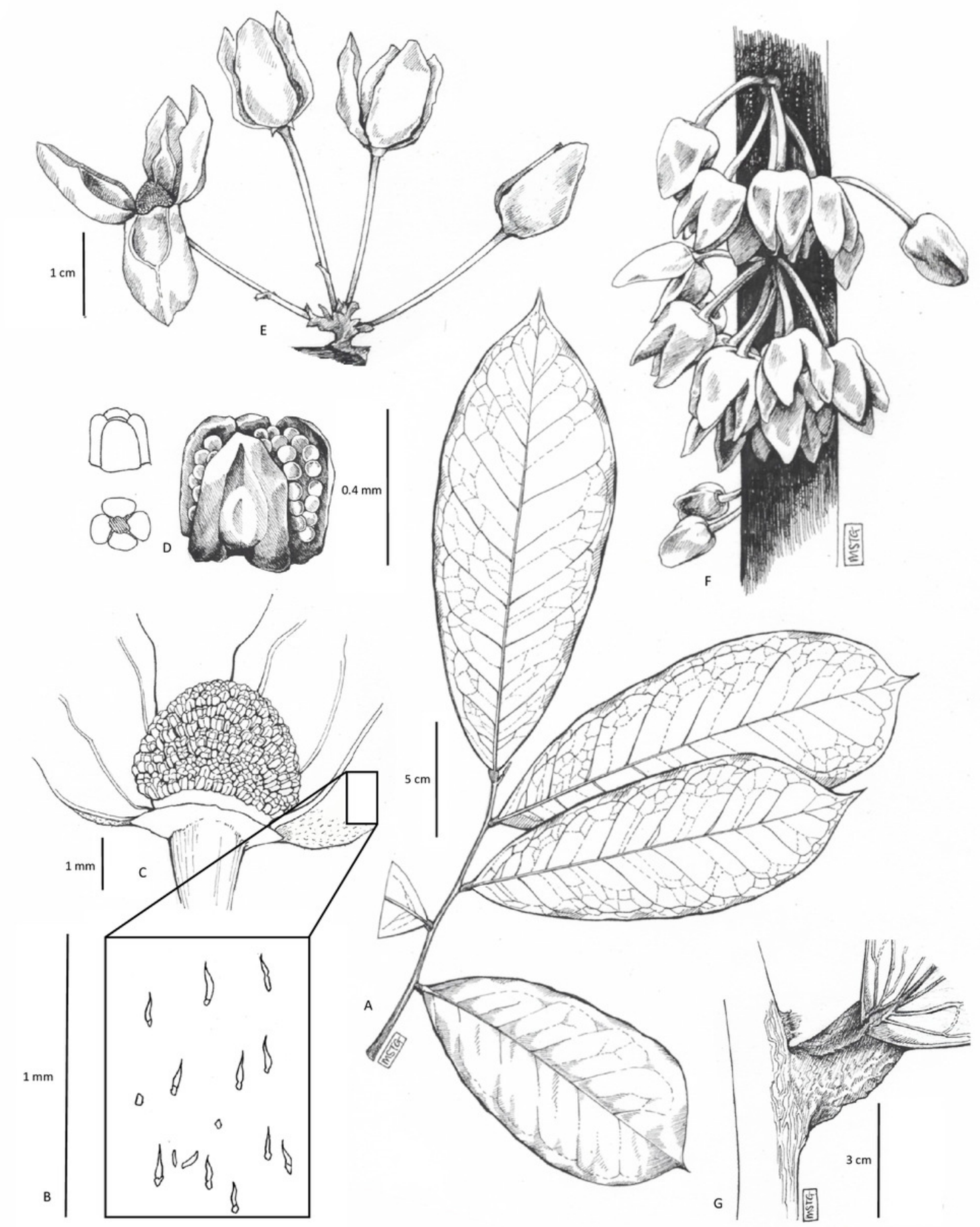
Figure 4

Global Distribution of Uvariopsis dicaprio, together with U. korupensis and $U$. submontana 


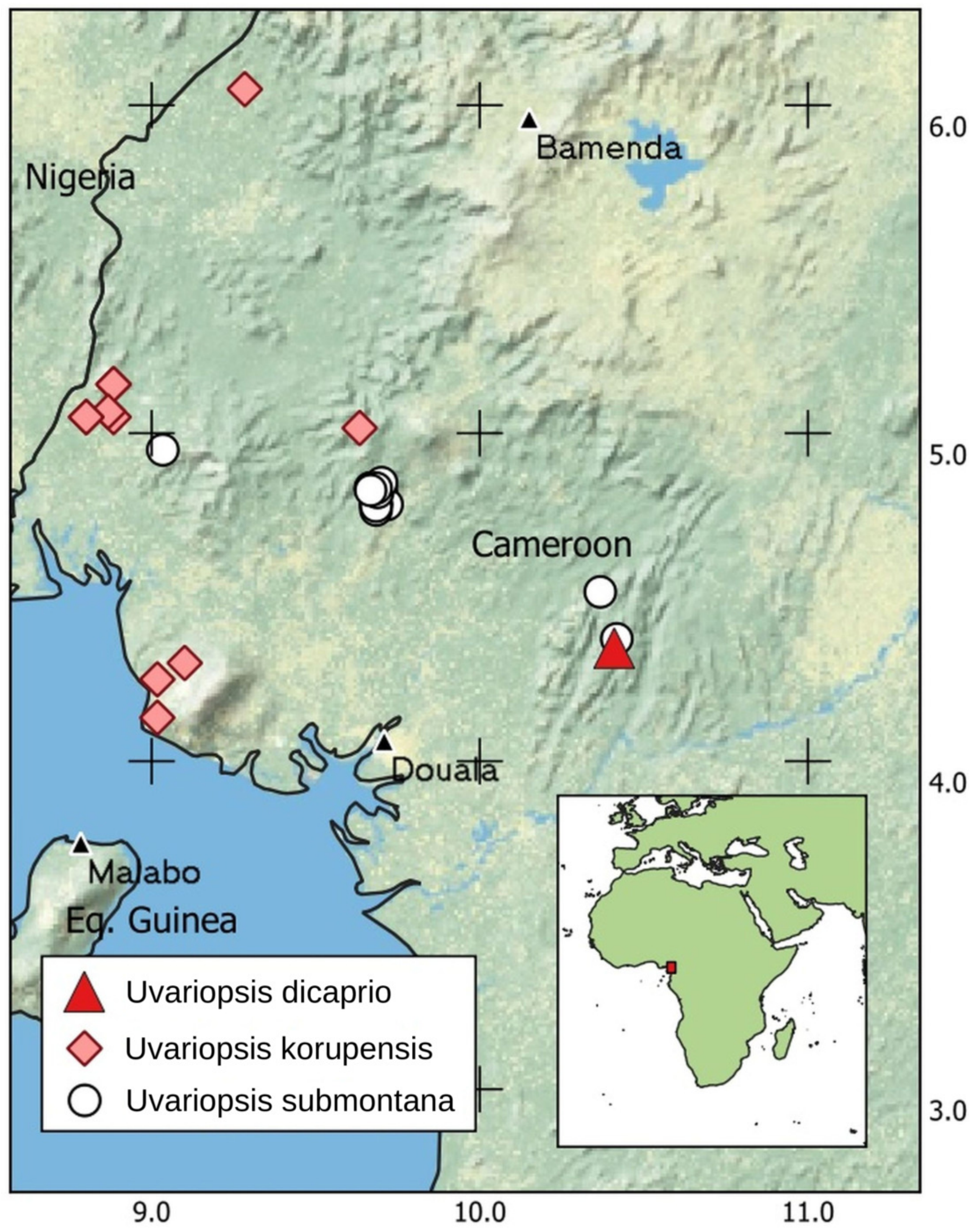




\section{Table $\mathbf{1}$ (on next page)}

Differential characters separating Uvariopsis dicaprio, U solheidii, U. korupensis and U.submontana.

Data for Uvariopsis solheidii taken mainly from Couvreur et al. (2021) and Cheek et al. (2011), for Uvariopsis korupensis Gereau \& Kenfack (2000), and for Uvariopsis submontana (Kenfack et al. 2003). 


\begin{tabular}{|c|c|c|c|c|}
\hline Character & $\begin{array}{l}\text { Uvariopsis } \\
\text { solheidii }\end{array}$ & $\begin{array}{l}\text { Uvariopsis } \\
\text { dicaprio }\end{array}$ & $\begin{array}{l}\text { Uvariopsis } \\
\text { korupensis }\end{array}$ & $\begin{array}{l}\text { Uvariopsis } \\
\text { submontana }\end{array}$ \\
\hline $\begin{array}{l}\text { Indumentum } \\
\text { of stem, } \\
\text { petiole and } \\
\text { abaxial } \\
\text { midrib }\end{array}$ & Tomentose & Glabrous & $\begin{array}{l}\text { Appressed } \\
\text { pubescent }\end{array}$ & $\begin{array}{l}\text { Appressed } \\
\text { pubescent }\end{array}$ \\
\hline $\begin{array}{l}\text { Leaf-blade } \\
\text { dimensions } \\
(\mathrm{cm})\end{array}$ & $\begin{array}{l}16.6-29 \times 5- \\
9.5\end{array}$ & $\begin{array}{l}17.7-20.3(-23) \\
\mathrm{x}(6.4-) 7-7.9\end{array}$ & $30-52 \times 9-14$ & $6-38 \times 5-11$ \\
\hline $\begin{array}{l}\text { Number of } \\
\text { secondary } \\
\text { nerves on } \\
\text { each side of } \\
\text { midrib }\end{array}$ & $8-13$ & $5-8(-9)$ & $13-20$ & $9-18$ \\
\hline $\begin{array}{l}\text { Number of } \\
\text { flowers per } \\
\text { inflorescence }\end{array}$ & $1-3$ & $(1-) 4-7$ & $2-3$ & $6-50$ \\
\hline $\begin{array}{l}\text { Flower shape } \\
\text { (mature bud) }\end{array}$ & Ovoid-conic & $\begin{array}{l}\text { Ovoid-conic to } \\
\text { pyramidal }\end{array}$ & $\begin{array}{l}\text { Ovoid-conic to } \\
\text { pyramidal }\end{array}$ & $\begin{array}{l}\text { Ovoid-conic to } \\
\text { pyramidal }\end{array}$ \\
\hline Petal colour & Wine brown & Yellow-green & Pink-purple & Pink-Purple \\
\hline $\begin{array}{l}\text { Petal } \\
\text { dimensions } \\
(\mathrm{mm})\end{array}$ & $7-10 \times 2.5-5$ & $\begin{array}{l}(14-) 16 \times(5.5-) \\
9\end{array}$ & $10-25 \times 5-10$ & $7-15 \times 5-7$ \\
\hline Petal texture & Thick, fleshy & Thin, leathery & Thick, fleshy & Thick, fleshy \\
\hline $\begin{array}{l}\text { Inner surface } \\
\text { petals }\end{array}$ & Tuberculate? & Smooth & Tuberculate & Tuberculate \\
\hline $\begin{array}{l}\text { Outer surface } \\
\text { petals }\end{array}$ & $\begin{array}{l}\text { Appressed- } \\
\text { pubescent }\end{array}$ & $\begin{array}{l}\text { Mostly naked, } \\
\text { hairs few, widely } \\
\text { scattered }\end{array}$ & $\begin{array}{l}\text { Appressed- } \\
\text { pubescent }\end{array}$ & $\begin{array}{l}\text { Appressed- } \\
\text { pubescent }\end{array}$ \\
\hline Petals at base & Free & Free & United & United \\
\hline
\end{tabular}




\section{Table 2 (on next page)}

Plant species globally endemic on current evidence to the area of the Ebo forest, Littoral, Cameroon.

Extinction risk assessment (IUCN Red List status from iucnredlist.org/ accessed 12 April 2021). 


\begin{tabular}{|l|l|l|l|l|}
\hline Species name & Family & Reference & Habit & IUCN status \\
\hline $\begin{array}{l}\text { Ardisia } \text { ebo } \\
\text { Cheek }\end{array}$ & Primulaceae & $\begin{array}{l}\text { Cheek \& } \\
\text { Xanthos }(2012)\end{array}$ & Herb & $\begin{array}{l}\text { Critically } \\
\text { Endangered }\end{array}$ \\
\hline $\begin{array}{l}\text { Crateranthus } \\
\text { cameroonensis } \\
\text { Cheek \& Prance }\end{array}$ & Lecythidaceae & $\begin{array}{l}\text { Prance \& } \\
\text { Jongkind } \\
(2015)\end{array}$ & Tree & $\begin{array}{l}\text { Critically } \\
\text { Endangered }\end{array}$ \\
\hline $\begin{array}{l}\text { Inversodicraea } \\
\text { ebo Cheek }\end{array}$ & Podostemaceae & $\begin{array}{l}\text { Cheek } \text { et al. } \\
(2017)\end{array}$ & Rheophyte & $\begin{array}{l}\text { Critically } \\
\text { Endangered }\end{array}$ \\
\hline $\begin{array}{l}\text { Kupeantha ebo } \\
\text { M.Alvarez \& } \\
\text { Cheek }\end{array}$ & Rubiaceae & $\begin{array}{l}\text { Cheek } \text { et al. } \\
(2018 \mathrm{~b})\end{array}$ & Small tree & $\begin{array}{l}\text { Critically } \\
\text { Endangered }\end{array}$ \\
\hline $\begin{array}{l}\text { Kupeantha } \\
\text { yabassi } \\
\text { M.Alvarez \& } \\
\text { Cheek }\end{array}$ & Rubiaceae & $\begin{array}{l}\text { Alvarez } \text { et al. } \\
(2021)\end{array}$ & Shrub & $\begin{array}{l}\text { Critically } \\
\text { Endangered } \\
\text { (provisional) }\end{array}$ \\
\hline $\begin{array}{l}\text { Palisota ebo } \\
\text { Cheek }\end{array}$ & Commelinaceae & $\begin{array}{l}\text { Cheek } \text { et al. } \\
(2018 \mathrm{a})\end{array}$ & Herb & $\begin{array}{l}\text { Critically } \\
\text { Endangered }\end{array}$ \\
\hline $\begin{array}{l}\text { Pseudohydrosme } \\
\text { ebo Cheek }\end{array}$ & Araceae & $\begin{array}{l}\text { Cheek } \text { et al. } \\
(2021)\end{array}$ & Herb & $\begin{array}{l}\text { Critically } \\
\text { Endangered } \\
\text { (provisional) }\end{array}$ \\
\hline $\begin{array}{l}\text { Uvariopsis } \\
\text { dicaprio Cheek } \\
\text { \& Gosline }\end{array}$ & Annonacaeae & This paper & Tree & $\begin{array}{l}\text { Critically } \\
\text { Endangered } \\
\text { (provisional) }\end{array}$ \\
\hline
\end{tabular}

3

4 